DOI: https://doi.org/10.30525/978-9934-26-108-4-5

Muslum Mursal Mursalov

Ph.D. in Economics, Senior Lecturer of Chair of «Economic Regulation» Azerbaijan State University of Economics (UNEC)

\title{
REGULATION OF THE BANKING SECTOR: PANDEMIC CHALLENGES AND DIGITAL SOLUTIONS
}

\section{Summary}

The article analyzes the current state of the world banking system. The main trends in its development in conditions of global instability are distinguished. The role of the coronavirus pandemic as a catalyst for the digital transformation of the banking sector is revealed. The article considers the development of regulatory innovations in the banking sector in the digital economy. The real situation in the field of regulatory activity and its specific features in this sector of the economy of the Republic of Azerbaijan are revealed. Using certain cases, the author shows the emergence of completely new, original forms of banking regulation, which have no analogues in the world practice and are possible due to a complex combination of a number of causes (financial crisis, technological revolution, coronavirus outbreak, etc.). The main directions of the impact of digitalization on the transformation of the process of regulation of banking activity are presented, a comprehensive study of which will allow to develop fundamentally new approaches to its improvement. The feasibility of implementing innovative practical measures to improve the efficiency of the banking regulation system was justified.

\section{Introduction}

As a result of the consequences of global disasters, the global banking community is undergoing major shifts that directly or indirectly affect the development of national banking systems. The post-crisis banking environment in some developed countries has many uncertainties. Taking into account risk factors such as the unpredictability of the global economic governance system, the possible large-scale sovereign debt crisis and imbalances in budgets and financial sectors, as well as the increase in inflation and signs of overheating of the economies of the leading emerging countries, there have been noticeable shifts in the development trends of the world banking system. The global banking sector benefited most from positive news about COVID-19 vaccines and a new U.S. administration which boosted capital markets in the final quarter of 2020.

The growing role of digitalization in the banking sector has changed the preferences of customers and their requirements for the quality of products and services provided. This was especially true in conditions of the COVID-19 
pandemic, which has caused interruptions in the activities of users of banking services and products. All sides of the public structure were affected. As part of the global response to COVID-19, the digital finance industry plays a key role in the design and delivery of services and innovative services and products that have partially mitigated the disruptions caused by the pandemic in many aspects of human life. In the context of emerging anti-pandemic contexts, a strong surge in interest in the broad potential of financial technology brings about the preservation of the livelihoods of people and businesses threatened by the pandemic, thereby enabling and sustaining within society cash flows, credit, deposits, investments, salaries, transfers at the national and regional levels.

The volatility of economic systems in a market economy had led to the fact that they were regulated under current conditions. This applies fully to banking, where the regulatory process - influenced by the global financial crisis, increasing various manifestations of uncertainty and the need to minimize their consequences - is becoming more diverse and complex. In banking regulation, there is an increasing emphasis on macroeconomic impact (instead of microeconomic) and the mandatory nature of regulatory rules (instead of advisory). The importance of reforming the global financial architecture, implementing global financial regulation, adapting it to the requirements of the digital economy is constantly on the agenda of various international forums. These topical issues are actively discussed in the world and domestic scientific circles, as well as among participants in the financial market, both abroad and in Azerbaijan.

\section{Part 1. Modern banking system and peculiarities of its functioning in conditions of coronavirus crisis}

As a specific area of international economic relations, the global banking system (GBS) is an important and integral part of the global financial market. Its essence lies in the organization of a legally fixed system of relations between the subjects of these markets for the purchase and sale of a wide range of banking services, the direction of financial resources from owners to borrowers. By combining different GBS (both national and individual integration groupings), it acquired characteristics in the process of operation. Among them, it is necessary to highlight, in particular, the following: a close combination of state and market regulation; regulation of market relations by international and domestic legal norms; transparency of market information and participants; unlimited number of market participants; diversity and diversification of banking products and services; increasing competition in the market between banks and non-bank financial and credit institutions and strengthening the role of its non-price methods [1, p. 46-57].

In the context of the globalization of financial markets, changes in the development of the GBS significantly affect the growth of the economy of many countries, increase the country's competitiveness in the global 
economic space, and increase the well-being of the population. This is amply demonstrated by the statistics that characterize the causes and manifestations of the global financial crisis of 2007-2008. A comprehensive study of modern trends and regional features of the development of the GBS allows us to identify evolutionary trends in world economic relations in the context of increasing global growth.

During the first decade of the post-crisis period, the dynamics of the GBS was high volatility. It should be noted that, according to the Top 1000 World Banks 2018 rating, the GBS, which for the first time in the last decade marked double-digit growth in profit and capital, may be on the verge of the longawaited renaissance. The capital of the first level in the ranking of 2018 compared to the version of the previous year increased by $12 \%$, which, starting in 2009, is the maximum indicator. Even more encouraging sign of industry sustainability is that capital is growing faster than assets. For the 1000 best banks in the world, total profit before tax increased by $15.6 \%$ (to 1,112 billion USD), and total return on equity (ROE) - to $11.82 \%$ [2].

Monitoring of various ratings and international research related to the development of the GBS revealed the following in:

- A marked geographical differentiation in the representation of global banks, in particular, a dramatic increase in the transnational capacity of banking leaders in developing countries. At the same time, China's largest banks, which occupy the first four lines of the world rating, act as key drivers of capital growth: they increased their total market capitalization by 144 billion USD. Thus, in the global banking industry we can state the consolidation of a new world order - without the dominance of the United States and with the dominance of Chinese banks [2].

- The narrowing of foreign expansion of transnational banks, primarily European and American, in connection with the global financial crisis. In the post-crisis period, gross cross-border capital flows fell by $65 \%$ in absolute terms and by 4 times compared to world GDP, which is exactly the opposite of pre-crisis trends. Moreover, about half of this decrease is due to the departure of large banks in Europe and the USA from foreign markets. Thus, in the period 2007-2017, the total volume of external loans and other requirements of eurozone banks decreased by 7.3 trillion USD, or $45 \%$ $[3$, p. 2, 6]. At the same time, the transnational positions of banks in Japan, China, Canada and Australia were strengthened, which expanded their penetration into foreign countries.

- Radical growth, qualitative development and high popularity of Islamic banking. According to most international economic experts, in modern conditions Islamic banking represents the most dynamic segment of the global financial market, which turned out to be the least exposed to crisis financial disasters and contributed to global economic stability [4, p. 9; 5, p. 4-5].

- A deepening digitalization of the banking business, characterized by the intensive introduction of new financial technologies. The digitalization of the 
banking sector becomes a decisive factor in the acquisition of competitive advantages by banks in both the national and global financial markets [6, p. 31-43]. Such a business model covers all interconnected functional blocks of banking and creates competition with Fintech companies that try to replace traditional banks.

Speaking about the modern banking system, it is important, in our opinion, to pay attention to the recent intensification of uncertainties, among which the coronavirus pandemic should be emphasized. More than 1.5 years have passed since the entire world was swept by the effects of the pandemic of new COVID-19 infection, accompanied by mass infection, dangerous viral strains and nationwide lockdowns. The pandemic shock has placed all the countries of the world in the face of new challenges. The need to balance between measures to protect human health, neutralize crisis processes, overcome recession and maintain financial stability has changed the scenario conditions for the development of all sectors of the world economy, including the banking sector. The depth and negative effects of the economic crisis caused by the COVID-19 pandemic are partially mitigated by unprecedented budgetary support measures. At the same time, countries that have limited capacity to refinance domestic and external debt are in the most difficult situation. It is expected that the effectiveness of the measures taken to combat the pandemic of coronavirus infection will largely determine the scenarios for the development of the world banking system in the short term.

After a long time marked by increasing infection rates, political and economic turmoil, the final quarter of 2020 brought some long-awaited positive news. The availability of effective COVID-19 vaccines as well as increasing clarity about a new U.S. administration and the Brexit deal reduced uncertainty and boosted capital markets. Global banks benefited most from these developments and market capitalization surged by $+17.6 \%$ qoq but remains below last year's level (-18.9\% yoy). The total shareholder return (TSR) of global top 100 banks outperformed the market and with $+25.0 \%$ qoq (-5.9\% yoy) achieved the strongest value across all industries [7].

The current state of the GBS is characterized by the following parameters [8]:

- After the collapse in Q1, global top 100 banks' market capitalization recovered in Q4 2020 and jumped by $+21.4 \%$ qoq. However, market cap of global top 100 banks is still far below the peak value in Q4 2019 (-17.2\% yoy) while the overall market managed to fully digest the losses from the first three quarters (MSCI World: $+9.6 \%$ qoq and $+5.6 \%$ yoy).

- Banks' average price/book (P/B) ratios increased significantly across most regions. U.S. banks' ratio rose by $0.31 \mathrm{x}$, once again above the hurdle of $1.00 x$, but Western European banks' P/B ratio improved relatively moderately by $0.13 x$ to just $0.56 \mathrm{x}$ on average.

- Despite a strong TSR performance in Q4, for the full year 2020 the banking sector lost shareholder value while other industries fully recovered over the year. Especially Western European banks showed a negative average 
TSR in 2020 of $-21.2 \%$ yoy (U.S.: $-5.1 \%$ yoy, BRICS: $-3.0 \%$ yoy, MSCI World: $+16.5 \%$ yoy).

Europe has been hit hard by the second wave of coronavirus cases and additional strict lockdowns in several Western European countries will delay the economic recovery. While GDP growth in the U.S. and BRICS countries is expected to continuously improve, Western European countries' GDP growth is expected to remain clearly negative in Q4 2020 and even Q1 2021. However, the rollout of the COVID-19 vaccine increases the hope for a corresponding stronger rebound in European growth in Q2 21 and going forward.

In the context of the coronavirus crisis, such key banking factors have developed:

- To limit the economic impact from the second COVID-19 wave, the European Central Bank expanded its monetary stimulus program PEPP (Pandemic Emergency Purchase Program) in December 2020 by a further 500 bn EUR, keeping the euro area yield curve on an ultra-low and flat level.

- The U.S. yield curve steepened slightly compared to the previous quarter after the U.S. Fed decided to maintain benchmark rates near zero as well as its current bond buying program but without extending the duration of these bonds.

- Low U.S. yields in line with significantly higher U.S. inflation rates put further pressure on the U.S. dollar development. The EUR/USD exchange rate increased by $+4.4 \%$ qoq ( $+9.6 \%$ yoy) and exceeds the value of $1.2-$ for the first time since April 2018.

- Bank results of the first two quarters were mainly impacted by significantly increasing loan loss provisions (LLPs). In Q3 2020, risk provisions normalized which clearly pushed global banks' profitability. In addition, European banks were able to slightly increase their earnings $(+1 \%$ qoq), thus achieving an average quarterly ROE of $7.7 \%,+1.6 \%$ above Q3 2019. However, these promising figures are unlikely to be sustainable as the current aggravation of the COVID-19 pandemic across Europe could lead to an uptick in LLPs again. The real test for banks' financial resilience will come in the first half of 2021 after the end of the moratoria and state aid programs for corporates.

- In Q3 2020, reported LLPs returned to pre-pandemic levels indicating that banks have reached sufficient provisions for the time being to balance future losses. U.S. banks' LLPs slumped by $-82 \%$ qoq (-14\% qoq) and Western European banks reduced LLPs by $-56 \%$ qoq (+16\% yoy). However, based on the current dynamic of the pandemic, further, much higher LLPs could be required in the coming quarters.

- Profitability of U.S. banks increased by $+5.4 \%$ p to $10.9 \%$ (-1.3\%p yoy) in Q3. Although U.S. banks were not able to keep up previous earnings growth (-10\% qoq), normalized LLPs and lower costs (-6\% qoq) boosted Q3 profits (+90\% qoq). 
- European banks were able to further reduce costs (-2\% qoq) and improve operational efficiency. In Q3, the cost-income ratio reduced for the third time in a row to $59 \%$.

- At the end of Q3 2020, corporate loan rates reached the highest value in two years. While most of the customer rates in the euro area were mainly unaffected by the COVID-19 pandemic, a higher demand for corporate loans as well as risk-adjusted pricing lead on average to increasing interest rates for corporate business over 2020 (+44bp since January 2020) [9].

Certain measures were taken during the coronavirus pandemic in Azerbaijan. So, banks actively working with small and medium-sized businesses tried to support this sector, which was severely affected by quarantine. Most of them at the beginning of spring 2020 launched the process of restructuring loans, and up to a certain amount we carried them through call centers. Some banks have reduced banking fees in order to reduce the costs of clients who suffered losses due to the pandemic and quarantine. Commissions for remittances, credit procedures, connection to acquiring and a number of other services were canceled or discounts were made. For customers who had problems paying for credit debts, a special plan was developed. Depending on the segment, benefits were paid (exemption from payments for up to 6 months, loan renewal, revision of payment schedules, etc.). Along with this, the crisis accelerated and expanded the use of digital technologies in the banking business of Azerbaijan.

\section{Part 2. Pandemic as a catalyst for digitalization of the banking system}

Like any large-scale shock, the current coronavirus pandemic is a catalyst for the development of civilization. Apparently, it came to us for a long time, and, whether we want it or not, in simple, traditional methods, we cannot cope with it. The world community is forced to quickly rebuild, to intensify as much as possible in all areas in order to find new, effective ways to adapt to the emerging habitat. One of these relevant solutions is the accelerated development and widespread introduction of innovative technologies, in other words, the digitalization of society. Let us take a closer look at the main directions and advantages of this process from the point of view of problems of the banking sector.

The need for different strategies for innovation and digital banking was evident in banking long before the pandemic. At least technology development, customer expectations for banking services grew, not least due to instant and personalized services provided by leading technology firms. Fintech companies such as Google, Yandex or Amazon have shown that this is possible and that all banks need their own digital transformation strategy. Over the past 20 years, the banking sector has developed at an accelerated pace: this was facilitated by the growing level of penetration of mobile communications and the Internet, as well as the technical literacy of 
customers, due to which banks were able to quickly introduce modern technologies [10, p. 82-83].

In the context of the pandemic of the coronavirus infection COVID-19 and the subsequent crisis in the global economy caused by widespread epidemiological restrictions, the digitalization of banking services and services is becoming especially popular for the banking sector. COVID-19 pandemic also changes behavior of consumers, pushing them to consideration and development of new tools and technologies. If in 2019, about $67 \%$ of bank customers preferred to visit bank offices personally, then current trends show that the digital transformation implemented by banks, as well as changes in customer behavior, will lead to an increase in the number of closed branches: as a result, the universalization of banking services in branches will increase [11].

The COVID-19 epidemic has already affected the preferences of Russian customers. According to the MasterCard study conducted in April, the following results are obtained: during the pandemic, $43 \%$ of customers in Russia preferred cashless cash payments, 22\% stopped using cash and began to use cards and other payment means, about $50 \%$ of customers began to use contactless cards more actively, $16 \%$ of customers first used contactless payments [10, p. 85].

Global practice shows an intertwining of the positive and negative effects of digitalization in general and in the banking sector in particular [12, p. 2, 13; 13, p. 136-137]. The most important positive effects of Fintech in the banking sector include:

- increasing banking (financial) accessibility;

- providing better quality and individual banking services;

- reducing transaction costs and accelerating the implementation of banking services;

- positive impact on financial stability due to increased competition;

- the possibility of using Fintech to improve the regulation of credit institutions.

The negative consequences of the digital transformation of banks include: the growth of risks, (primarily cyber risks), the high cost of implementation. The development of Fintech determined the emergence of Fintech companies, which began to actively compete with traditional banks.

BCBS presented the following classification to Fintech innovations: open APIs, applications related to data processing (big data analytics, machine learning, predictive modeling), blockchain (including smart contracts), customer identification and authentication (biometrics), cloud technologies, Internet of Things (IoT) and mobile technologies, artificial intelligence (bots, automation in finance, etc.) [14, p. 9] The use of these innovative technologies by banks requires a radical change in information systems and improved management of old and new risks [15, p. 514-517]. These technologies reduce barriers to entry into the market sector for new 
participants (Fintech companies), providing low-cost infrastructure and access to direct channels for providing banking products and services to customers (using digital platforms, ecosystems, aggregators).

The growth of Fintech companies has led to increased competition with traditional banks, which negatively affected the size and sustainability of bank revenues: this encourages banks to improve digital interfaces and continue digital transformation to increase competitiveness. According to BCSG, when assessing the impact of Fintech on banking, the digital transformation of banks, it is important to take into account two circumstances: the degree of implementation of basic technology in society and the prevalence of technological know-how among the population as a whole.

Considering the digital transformation of traditional banks, BCBS identifies five basic scenarios (and the possibility of their integrated implementation in practice is stipulated).

Modernization and digitalization of existing traditional banks. Existing banks are independently digitized and modernized in order to maintain relations with customers and continue to produce and sell basic banking services using innovative technologies (changing bank business models). This process is commonly called the digital transformation of traditional banks;

- new bank (neo-bank). New, technological neo-banks are being created that provide a classic set of banking services (as a rule, these banks are the result of the successful development of Fintech companies). Neo-banks have no branches, they are not burdened with the old infrastructure and can use new technologies at a lower price, faster, using applications for smartphones or Internet platforms. They target individuals, entrepreneurs, small and medium-sized businesses, use scalable infrastructure using cloud providers or API-based systems to better interact with customers online, in mobile and social networks. The neo-bank income model mainly involves commission;

- distributed bank (distribution of financial services among Fintech companies and banks). Financial services and products are becoming more modular and can be provided by banks and other financial service providers (e.g., Fintech or Bigtech companies). In this case, the digital interface of the client can belong to any company in the market;

- excluded bank (existing traditional banks become service providers, and relations with customers belong to Fintech companies). Existing (traditional) banks become financial service providers (their banking license is used) and cede direct relations with customers to other financial service providers Fintech and Bigtech companies (various kinds of digital platforms and aggregators are widely used), which allows you to provide a variety of financial services from different suppliers). The excluded bank may or may not retain the balance sheet risk of these transactions depending on the contractual relationship with the above companies;

- without an intermediary bank (disintermediation). Existing traditional banks are no longer significant market participants, since there is no need for 
mediation or the use of a trusted third party. Banks are being pushed out of the financial transactions of customers by more flexible and competitive neobanks, Fintech companies that meet the demand of end consumers. In this scenario, customers may be able to personally select services and a provider rather than select such services with the help of an intermediary bank (emergence of ecosystems) [14, p. 26-27].

In the implementation of all the above scenarios, banks are increasingly entering into partnerships and/or outsourcing operating support for financial services to third-party suppliers, including Fintech companies (however, risks and transaction obligations must be «serviced» by the bank).

\section{Part 3. Transforming banking regulation in a new reality: digital choice}

In Azerbaijan, international regulatory reforms were taking on specific features. It is known that within the framework of the concept of activity of the mega-regulator of the fi-ness market, which in our country is the Central Bank (CBA), regulation here is characterized by high centralization. In this regard, in the context of the consistent implementation of the requirements of the international norms of the Basel Committee on Banking Supervision (BCBS), certain difficulties and additional risks may arise. Account should also be taken of the inadequate substantive, legislative and regulatory frameworks of the regulatory process, the streamlining and development of which will require considerable effort. The pandemic of coronavirus also had an unfavorable effect on the economic environment in the republic, which was accompanied by a weakening of the stability of economic life, a deterioration in the financial situation of producers of goods and services, who will need significant state support. All these and other related factors together determine the complexity and multifaceted regulatory procedures in the banking system of Azerbaijan, the importance of their innovation taking into account the accumulated progress of creative experience and new phenomena in domestic and foreign practice (for example, digitalization) in the context of the urgent needs of all segments of this system.

Today, experts of many countries agree on the adoption in the emerging economy of the so-called "new reality», characterized by revolutionary transformations in the markets of informatics and telecommunications, on the one hand, and in the financial markets, on the other [16, p. 811; 17, p. 28-33; 18 , p. 3,$17 ; 19$, p. $150-154 ; 20 ; 21$, p. 116, 124, 127]. In the current conditions, the current methods and systems of banking regulation are becoming more complicated and acquiring modern features. At the same time, completely new, original forms of it arise, which had no analogues in world practice and became possible due to a complex combination of a number of causes (financial crisis, technological revolution, coronavirus outbreak, etc.) [22; 23; 24; 25]. New financial technologies and the resulting digital transformation of the banking sector, which have a noticeable impact on 
changes in its modern appearance, are being discussed in a particularly lively manner. Once and temporarily with highlighting the positive aspects of the digital scenario for the development of this sphere of the economy, close attention is paid to the risks manifested in its implementation [26, p. 55-56; 27; 28, p. 70-71; 29].

The banking regulatory system in Azerbaijan increasingly demonstrates commitment to the ideas of international institutions, tries to harmoniously integrate into international regulatory trends, increases capital requirements, together with the international banking community forms a more stable structure that protects banks from crisis shocks. The measures taken to modernize the banking regulation system have a positive impact on the functioning of national credit institutions and, first of all:

- expands the potential of banks to cover their risks;

- improves the quality of capital;

- creates a favorable environment for the growth of liquidity of credit institutions;

- contributes to leveling the cyclical economic development of banks.

At the same time, analytical monitoring of the real situation in the domestic banking sector showed that certain imbalances still existed in the banks' activities, the need to eliminate them confirmed the importance of further improving regulatory innovations.

The rapid development of digital technologies leads to an unprecedented transformation of the banking industry, which is reflected in a change in the competitive environment, as well as the process of interaction between banks and regulators. In such circumstances, the traditional regulatory framework needed to be improved and new types of effective regulatory solutions aimed at structurally developing the financial market and ensuring the sustainability and competitive potential of banks in the face of global technological and behavioral changes. In the economic literature, effective banking regulation is characterized, in particular, by the optimal level of regulatory burden, which shows how burdensome it is for financial institutions to comply with regulatory measures $[30$, p. 8]. It is important to understand that increasing this burden is usually the result of improved regulatory measures aimed at ensuring the sustainable functioning of financial institutions. Therefore, it is advisable to talk not about its minimization, but rather about achieving and maintaining the optimal level.

Transformational changes offer a number of benefits, but at the same time involve new risks (micro-level and systemic) that require regulatory responses. The widespread introduction of new business models among nonbank technology companies can lead to significant transformations and the emergence of new sources of systemic risk, which cannot be eliminated using standard prudential tools. Risk classification and management approaches are likely to require further development in the future. In particular, operational and cyber risks, which are currently considered specific, can be considered 
systematic [14, p. 34-35]. The potential negative impact of digital transformation processes on the stability of traditional banking institutions can be significantly reduced by optimizing their management using regulatory tools.

In the context of the interest of financial regulators in the development of financial innovations and the introduction of more effective regulatory systems, one of the new directions was the development of a new approach to data-based regulation. The basis for the formation of this approach was the expansion of the use of regulatory technologies (Regtech) both in terms of monitoring digital transformation and responding to internal operational tasks [31, p. 10-11]. Financial regulators of a number of countries, in particular Canada, Great Britain, Singapore, India and Australia, have already announced their readiness to use Regtech [32, p. 7, 12].

In the context of managing the digital transformation process, Deloitte consulting company distinguishes between three roles of financial regulators. The first corresponds to their role as coordinator, which plays an active role in stimulating innovation and competition in financial markets. At the same time, its main characteristics as a coordinator are regulatory flexibility and a regulatory ecosystem. It is assumed that in this case, banks will be able to effectively manage risks associated with financial technologies. The second is the deterrent, whose role is to respond to emerging issues and address gaps and inconsistencies in regulatory requirements. Limiting risks can reduce the depth and breadth of financial innovation. Thirdly, this is an advisory role of financial regulators, the strengthening of which will contribute to the further improvement of this process [33, p. 5-6]. The combination of the three roles is the most optimal, since each of them allows solving strictly defined aspects of banking regulation.

At the current stage of digitalization of the banking industry, a transformation of the role of the regulator and the development of fundamentally new approaches to regulating the activities of participants in the financial market (both traditional and new, whose activities go beyond the boundaries of the banking sector). At the same time, closer interaction between the regulator and supervised organizations is necessary, as well as increased adaptability and predictability of regulation, clarification of approaches to the process of banking regulation taking into account industry and digital challenges [34, p. 19-49].

\section{Conclusions}

1. Unlike many past shocks, COVID-19 is not a banking crisis; it is a crisis of the real economy. Banks will surely be affected as credit losses cascade through the economy and demand drops. But the problems are not self-made. Global banking entered the crisis well capitalized and is far more resilient than it was 12 years ago. Our latest research indicates that in almost all COVID-19 scenarios, the vast majority of banks should survive. Further, we 
expect that most institutions can regain their 2019 ROE within five years, provided they are willing to do the hard work necessary on productivity and capital management. The farsighted among them will do even better. Such banks can capitalize on some deep-seated and accelerating trends to rethink their organization, business model, and reason for being and to set themselves up for long-term success.

2. The COVID-19 pandemic slammed shut a decade-long window of opportunity for banks. Banks had spent the time building capital reserves a regulatory requirement whose importance is evident in light of the current crisis. However, most industry incumbents did not use the boom to prepare their businesses fully for what is shaping up as a significant bust. Banks, like other sectors of the economy, may face some difficulties, but we see a favorable prospect. We believe that moment is right for banks to affirm their dual role as sources of stability against the pandemic and as beacons to the societies and communities they serve in the post- COVID-19 world. They must act because they have a crucial role to play in the work to restore and sustain livelihoods in their communities.

3. Currently, the digital transformation of existing banks is characterized by the comprehensive implementation of scenarios formulated by BCBS and directly related to the interaction of banks with Fintech companies, as well as the emergence of neo-banks, which, in general, increases competition in the banking sector.Traditional banks interact with Fintech companies in different ways: they compete fiercely, and work closely together. In this regard, regulators need to check whether current regulation provides the conditions for maintaining financial stability. The result of digitalization was the fact that banks are currently investing heavily in cybersecurity. The participation of Fintech companies, together with traditional banks in settlements, directly affects financial stability.

4. In view of the above, in order to improve the efficiency of the banking regulatory system, it would be appropriate to implement the following measures:

- identification of outdated and overlapping regulatory requirements;

- development of approaches that ensure the development of banking partnerships and the expansion of their range of available banking operations;

- improving the technological effectiveness of regulation and expanding the use of regulatory and supervisory technologies by regulatory authorities themselves.

The proposed measures will contribute to the improvement of banking regulation in the context of digital transformation, the objective perception by regulators of digital realities and the development of adequate solutions to respond to them, and ultimately to achieve a balance between stimulating innovation, protecting the rights of consumers of banking services and ensuring financial sustainability. 


\section{References:}

1. Allen F., Carletti E. (2012) The Roles of Banks in Financial Systems / The Oxford Handbook of Banking. Second Edition (Oxford Handbooks). Edited by A.N. Berger, P. Molyneux and J.O.S. Wilson. Oxford: Oxford University Press. March 2.

2. Myles D. (2018) Top 1000 World Banks 2018. The Banker, no. 7. URL: https://www.thebanker.com/Top-1000/2018/Top-1000 (accessed 22 June 2021).

3. McKinsey Global Institute. (2017) The New Dynamics of Financial Globalization. August 22. URL: https://www.mckinsey.com/industries/financial-services/our-insights/thenew-dynamics-of-financial-globalization (accessed 22 June 2021).

4. IFSB (2016) Islamic Financial Services Industry Stability Report 2016. Kuala Lumpur, May. URL: https://www.ifsb.org/islamic-financial-services-industry-stabilityreport-2016 (accessed 22 June 2021).

5. Nagimova A. Z. (2021) Islamskie finansy $v$ stranah SNG [Islamic Finance in the CIS Countries]. Moscow: INFRA-M. DOI: 10.12737/ 1182772

6. Manyika J., Lund S., Singer M., White O., Berry C. (2016) Digital Finance for All: Powering Inclusive Growth in Emerging Economies. McKinsey Global Institute. September.

7. Stickling H.-G., Rotermann B., Bauer E. (2021) The Banking Sector Between Hope and Fear. zeb.market.flash Q4 2020. Issue 35, January 12. URL: https:// www.bankinghub.eu/banking/research-markets/banking-sector-q4-2020 (accessed 22 June 2021).

8. McKinsey (2020) No Going Back: New Imperatives for European Banking. May 18. URL: https://www.mckinsey.com/industries/financial-services/our-insights/no-going-backnew-imperatives-for-european-banking (accessed 22 June 2021).

9. EBS (2020) Walking a Tightrope.COVID-19 and Expected Capital Shortfalls for European Banks. URL: https://zeb-consulting.com/en-DE/Publications/European-BankingStudy-2020-2nd-edition (accessed 22 June 2021).

10. Sokolinskaya N. E., Zinovieva E. A. (2020) Bankovskij sektor do i posle pandemii [Banking sector before and after the pandemic]. Financial markets and Banks, issue 6, pp. 81-86.

11. Mamchic R. (2020) Drugoj banking: razvitie bankovskoj otrasli posle koronavirusa [Other banking: development of banking industry after coronavirus]. Банковское обозрение, issue 5. URL: https://bosfera.ru/bo/drugoy-banking (accessed 25 September 2020). (in Russian)

12. Philippon T. (2017) The fintech opportunity. BIS Working Papers No. 655. August. Basel: Bank for International Settlements. URL: https://www.bis.org/publ/work655.pdf (accessed 15 August 2020).

13. Carbo-Valverde S. (2017) The impact of digitalization on banking and financial stability. Journal of Financial Management Markets and Institutions, vol. 5, no. 1, pp. 133-140.

14. BIS (2018) Sound practices: Implications of Fintech developments for banks and bank supervisors. February. Basel: Bank for International Settlements. URL: https://www.bis.org/ bcbs/publ/d431.htm (accessed 15 August 2020).

15. Lavrushin O. I., Solovev V. I., et al. (2020) Bankovskie informacionnye sistemy i tehnologii [Banking Information Systems and Technologies]. Moscow: Knorus. (in Russian)

16. Panova G. S., Yarygina I. Z., Bolonina A. I. et al. (2020) Banki i bankovskij biznes $\mathrm{v}$ globalnoj ekonomike [Banks and banking business in the global economy]. Moscow: MGIMO-Universitet. (in Russian) 
17. Teteryatnikov K. S. (2017) Novaja realnost/normalnost v mirovoj jekonomike i finansah [New reality/normality in the world economy and finance]. International Economy, no. 12, pp. 28-36.

18. Yudaeva K. (2013) New Normal dlja Rossii [New Normal for Russia]. Moscow: Publishing House «Delo» RANEPA.

19. Flower G., Fawcett P., Harle S. (2012) Banking: In Search of Relevance: A New Model for a New Reality. Leicestershire: Troubador Publishing Ltd.

20. Le Boulay G., Saudjana E., Dany O. et al. (2019) The New Reality for Wholesale Banks. Boston: Boston Consulting Group.

21. Medvedev D. A. (2015) New Reality: Russia and Global Challenges. Russian Journal of Economics, vol. 1, no. 2, pp. 109-129. DOI:10.1016/j.ruje.2015.11.004

22. Adarkar A., Dhar A., Gangul S. et al. (2020) Transforming the US consumer bank for the next normal. McKinsey Company.

23. Asif C., Dallerup K., Hauser S. et al. (2020) Reshaping retail banking for the next normal. McKinsey Company, 13 p.

24. Buehler K., Dietz M., Nadeau M-C. et al. (2020) Stability in the storm: US banks in the pandemic and the next normal. McKinsey Company, $12 \mathrm{p}$.

25. Lubkova E. M., Shilova A. E., Ermolaeva G. S. (2020) New Reality of the Banking Market: E-Banking and M-Banking (The Russia Case Study). Journal of Advanced Research in Law and Economics. vol. 10, no. 2(40), pp. 574-582. DOI: 10.14505/ jarle.v10.2(40).18

26. Ganchar L. S. (2019) Riski regulirovanija bankovskogo sektora [Risks of regulation of the banking sector]. Financial markets and banks, no. 2, pp. 50-57.

27. Constâncio M., Wyman O. (2017) The future of finance and the outlook for regulation. URL: https://www.ecb.europa.eu/press/key/date/2017/html/ecb.sp171109. en.html (accessed 20 June 2021).

28. Kryvtsun I. M. (2019) Digitalization Risks: Classification and Protection (on an Example of Banks Activity). Economic studies, no. 3(25), pp. 69-71.

29. Mahajan R., Parthasarathy S., Jain V. (2018) Managing Risk in Digital Transformation. Deloitte, India, 14 p. URL: https://www2.deloitte.com/content/dam/ Deloitte/in/Documents/risk/in-ra-managing-risk-in-digital-transformation-1-noexp.pdf (Retrieved 20.06.2021).

30. Golodnikova A. E., Efremov A. A., Sobol D. V. et al. (2018) Reguliatornaia politika $v$ Rossii: osnovnye tendencii i arhitektura budushhego [Regulatory policy in Russia: the main trends and architecture of the future]. Moscow: Center for Strategic Research. (in Russian)

31. Treleaven P. (2015) Financial Regulation of Fintech. The Journal of Financial Perspectives, vol. 3, no. 3, pp. 114-121.

32. Podder S., Pisanu G., Ghosh B. et al. (2018) Regtech for regulators. Re-architect the system for better regulation. Accenture Report. World Government Summit. URL: https://www.worldgovernmentsummit.org/api/publications/document?id=5ccf8ac4e97c-6578-b2f8-ff0000a7ddb6 (accessed 20 June 2021).

33. Brennan S., Dobra-Kiel A. (2019) Digital transformation meets regulation 4.0 in 2030. Part 1/3: Coping with disruptive innovation. London: Deloitte LLP, 7 p. URL: https://www2.deloitte.com/content/dam/Deloitte/uk/Documents/financial-services/ deloitte-uk-digital-transformation-meets-regulation-part1.pdf (accessed 20 June 2021).

34. World Bank Group (2020). Global Financial Development Report 2019/2020: Bank Regulation and Supervision a Decade after the Global Financial Crisis. Washington. 